\title{
Cryostorage of immature and mature human testis tissue to preserve spermatogonial stem cells (SSCs): a systematic review of current experiences toward clinical applications
}

This article was published in the following Dove Press journal:

Stem Cells and Cloning:Advances and Applications

Nima Pourhabibi Zarandi ${ }^{1, *}$ Guillermo Galdon',*

Stanley Kogan ${ }^{1,2}$

Anthony Atala ${ }^{1,2}$

Hooman Sadri-Ardekani ${ }^{1,2}$

'Wake Forest Institute for Regenerative Medicine, Wake Forest School of Medicine, Winston-Salem, NC, USA; ${ }^{2}$ Department of Urology, Wake Forest School of Medicine, Winston-Salem, NC, USA

*These authors contributed equally to this work
Correspondence: Hooman Sadri-Ardekani

Wake Forest School of Medicine,

Wake Forest Institute for Regenerative

Medicine, 39I Technology Way,

Winston-Salem, NC 27IOI USA

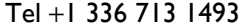

Fax +I 3367135754

Email hsadri@wakehealth.edu
Abstract: While the survival rate of children with cancer is increasing, preserving fertility for prepubertal boys is still a challenge. Although intracytoplasmic sperm injection (ICSI) using frozen sperms has revolutionized infertility treatment, it is not applicable for the patients who undergo chemotherapy before puberty since spermatogenesis has not begun. Therefore, preserving spermatogonial stem cells (SSCs) as an experimental option can be provided to prepubertal patients at a risk of damage or loss of their SSCs due to cancer treatments and developmental or genetic disorders. Using frozen SSCs in testicular tissue, successful SSC autotransplantation in mouse and nonhuman primates has shown a promising future for SSC-based cell therapy. Cryopreservation of testicular tissue containing SSCs is the first step to translate SSC-based cell therapy into clinical male infertility treatment, and in the investigation into SSCs, it is very important to evaluate their quantity and functionality during this process. This systematic review summarizes the published data on cryopreservation techniques in human testis tissue for potential utilization in future clinical applications.

Keywords: testis, spermatogonial stem cell, tissue banking, cryopreservation, male infertility, transplantation

\section{Introduction}

Advances in developmental and cell biology have allowed for extension of previous knowledge and experiences to more specialized areas of medicine, including reproduction. ${ }^{1,2}$ As has been described first in mouse models experimentally, spermatogonial stem cells (SSCs) have been used to generate sperm either in vivo ${ }^{3}$ or in vitro. ${ }^{4} \mathrm{SSC}$ transplantation has been tried successfully in different species ${ }^{5}$ including nonhuman primates, ${ }^{6}$ but not yet in humans. Progress in achieving successful and efficient in vitro spermatogenesis is less advanced than SSC transplantation but is promising as newer approaches, ie, the use of three-dimensional (3D) culture systems, are developing and becoming more refined. ${ }^{7-9}$

Various groups of patients such as cancer survivors, those with idiopathic nonobstructive azoospermia, and those with Klinefelter syndrome (KS) are examples of patients who may benefit from regenerative treatments using SSC technology either in vivo or in vitro when available in the future (Figure 1). Cancer survivors are the group that may benefit the most from this technology. In the past three decades, the survival rate of patients suffering from cancer has increased significantly. ${ }^{10,11}$ However, one of 


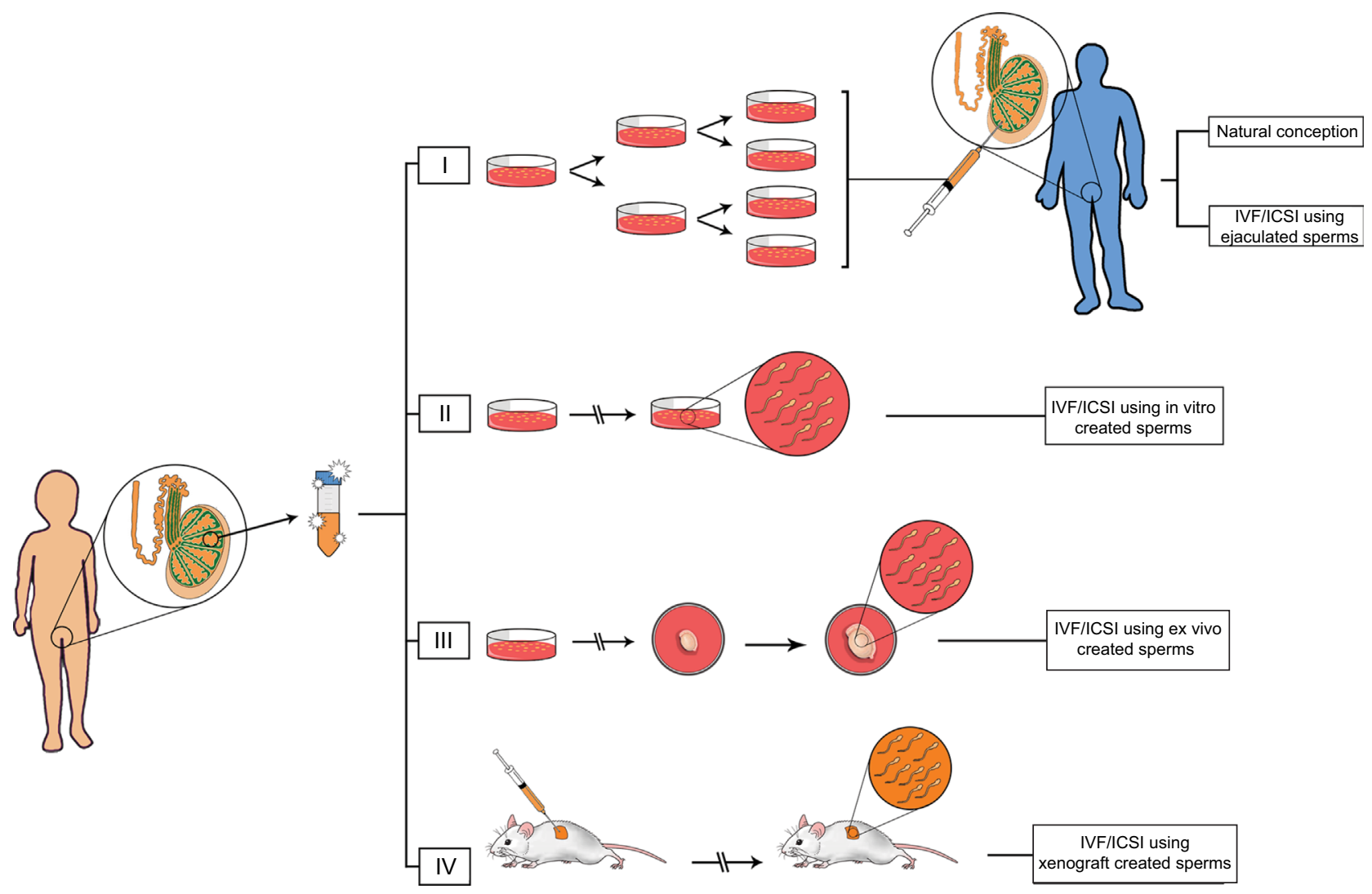

Figure I Potential future clinical applications using stored testicular tissue from high-risk patients. I. isolation and in vitro propagation of SSCs to have adequate number of SSCs for transplantation. Patients will try for natural conception or IVF/ICSI. II. Isolation of testicular cells and in vitro differentiation of cells into sperms and use in IVF/ICSI. III. Ex vivo culturing of testicular tissue to differentiate SSCs to sperms and use in IVF/ICSI. IV. Xenografting of cryopreserved tissue under the skin at the back of mouse until they differentiate to sperms and are used for ICSI/IVF. These options are all experimental and not clinically available.

Abbreviations: ICSI, intracytoplasmic sperm injection; IVF, in vitro fertilization; SSCs, spermatogonial stem cells.

the most common long-term complications of cancer treatments is the subsequent difficulty to conceive a child. ${ }^{12}$ Semen cryopreservation is often offered to adult patients before the start of chemotherapy or radiation. Unfortunately, this option is not available for pediatric patients prior to the onset of puberty. Investigators have postulated that cryopreservation of testicular tissue prior to the start of gonadotoxic treatments could open the door for future fertility treatments. Many groups have tried different methods to cryopreserve human testicular samples to maintain morphology, viability, and functionality of the cells after freezing and thawing. This article aimed to systematically reviewing the evolution of human testicular tissue cryopreservation and its effect on subsequent SSC propagation and to gather, organize, and compare data about this topic present in the literature.

\section{Methods}

The electronic database MEDLINE was systematically searched via PubMed using the following terms:
- Spermatogonia (MeSH): euploid male germ cells of an early stage of spermatogenesis, derived from prespermatogonia. With the onset of puberty, spermatogonia at the basement membrane of the seminiferous tubule proliferate by mitotic and then meiotic divisions and give rise to the haploid spermatocytes.

- Tissue banks (MeSH): centers for acquiring, characterizing, and storing organs or tissue for future use.

- Cryopreservation (MeSH): preservation of cells, tissues, organs, or embryos by freezing. In histological preparations, cryopreservation or cryofixation is used to maintain the existing form, structure, and chemical composition of all the constituent elements of the specimens.

- Freezing (MeSH): liquids transforming into solids by the removal of heat.

- Vitrification (MeSH): The transformation of a liquid to a glassy solid, ie, without the formation of crystals during the cooling process.

- Culture (All fields) 
The following combination of words was used for search: ("spermatogonia" [mesh]) and ("tissue banks" [mesh]) or ("cryopreservation" [mesh]) or ("freezing" [mesh]) or ("culture" [all fields]). Articles published in languages other than English were excluded, and we only included articles dealing with human materials. Final search was accomplished on March 1, 2018, and initially, 130 articles were identified. After reviewing the abstracts, 63 articles were selected for full-text review. The main inclusion criterion was presenting the original data from cryopreservation of testicular tissues or cells, for either clinical banking or fundamental research. After full-text review, 31 articles directly from MEDLINE search or indirectly via other selected manuscripts were included in this systematic review (Figure 2).

\section{Results}

In the past two decades, several groups have worked on techniques of freezing human testis materials. Different cryoprotectants such as dimethyl sulfoxide (DMSO) and ethylene glycol (EG) have been studied, and different cooling methods including slow freezing ie, uncontrolled (Figure $3 \mathrm{~A}$ and $\mathrm{B}$ ) and controlled rates (Figure 3C); and vitrification (Figure 3D) have been tried for cryopreservation. Table 1 summarizes all the studies, and Table 2 shows a comparison Search through PubMed using keywords: Spermatogonia,
tissue banks, cryopreservation, freezing, vitrification, and
culture.

Excluding articles published in any language other than English and including articles dealing with human materials only.

Selection via full-text review;

Inclusion criteria:

- Studies involving cryopreservation of testicular tissues/cells, for either clinical banking or fundamental research.

Exclusion criteria:

- Not used cryopreserved tissue/cells

- Review articles lacking original data.

Total number of articles included and discussed in this systematic review:

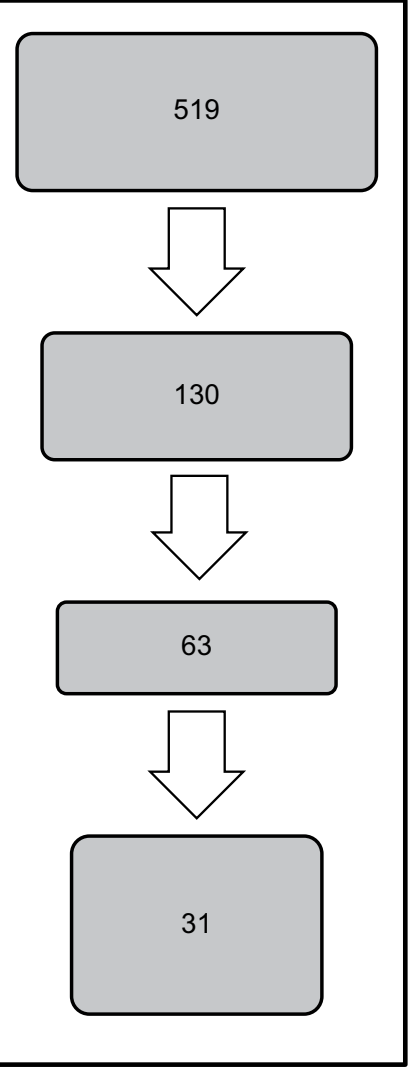

Figure 2 Article selection flowchart.
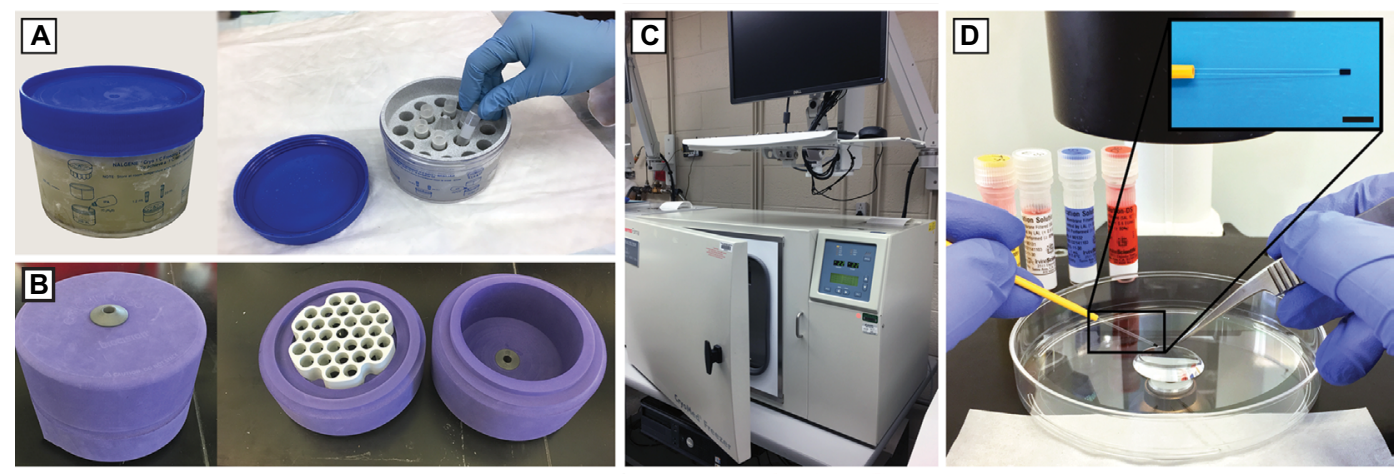

Figure 3 Different methods for cryopreservation of testicular tissue. (A) Nalgene ${ }^{\circledR}$ Mr. Frosty ${ }^{\circledR}$ container using isopropyl alcohol and (B) CoolCell ${ }^{\otimes}$ cell-freezing container without alcohol, both $(\mathbf{A}$ and $\mathbf{B})$ with a cooling rate of $-1^{\circ} \mathrm{C} / \mathrm{min}$. (C) Programmable control rate freezer that can be programmed by software for customized cooling rates. (D) Vitrification; showing vitrification rod (cryostraw) and solutions (scale bar $=5 \mathrm{~mm}$ ). 
Table I Summary of all studies that were included in this systematic review

\begin{tabular}{|c|c|c|c|c|c|c|c|}
\hline Year & Study & $\begin{array}{l}\text { Number of } \\
\text { patients }\end{array}$ & Indication & $\begin{array}{l}\text { Patients' age } \\
\text { range (year) }\end{array}$ & $\begin{array}{l}\text { Frozen } \\
\text { material }\end{array}$ & Freezing method & Cryoprotectant \\
\hline 2000 & Bahadur et al $^{13}$ & 2 & Oncology & 8 and 13 & Tissue & $\begin{array}{l}\text { Liquid nitrogen } \\
\text { vapor phase }\end{array}$ & Glycerol \\
\hline 2001 & Brook et $\mathrm{a}^{26}$ & 5 & Infertility & $22-35$ & Isolated cells & CRF & $\begin{array}{l}\text { DMSO, } \\
\text { I,2-propanediol, } \\
\text { ethylene glycol, glycerol }\end{array}$ \\
\hline 2005 & Keros et al ${ }^{14}$ & 16 & Unclear & $27-42$ & Tissue & CRF & $\begin{array}{l}\text { Glycerol, } \mathrm{PrOH} \text {, and } \\
\text { DMSO }\end{array}$ \\
\hline 2006 & Kvist et al ${ }^{19}$ & 8 & Cryptorchidism & $1-5$ & Tissue & CRF & Ethylene glycol \\
\hline 2007 & Keros et al ${ }^{17}$ & 5 & Oncology & $2-14$ & Tissue & CRF & DMSO \\
\hline 2007 & Wyns et $\mathrm{a}^{22}$ & 11 & Cryptorchidism & $2-12$ & Tissue & CRF & DMSO \\
\hline 2008 & Wyns et $a^{28}$ & 5 & Hematology/oncology & $7-14$ & Tissue & CRF & DMSO \\
\hline 2009 & $\begin{array}{l}\text { Sadri-Ardekani } \\
\text { et } \mathrm{al}^{31}\end{array}$ & 6 & $\begin{array}{l}\text { Orchiectomy (prostate } \\
\text { cancer) }\end{array}$ & N/A & Tissue & $\begin{array}{l}\text { Insulated container } \\
\text { in a }-80^{\circ} \mathrm{C} \text { freezer }\end{array}$ & DMSO \\
\hline 2010 & Ginsberg et a $\left.\right|^{43}$ & 14 & Oncology & $0.25-14$ & Tissue & CRF & DMSO \\
\hline 2011 & Van Saen et $\mathrm{a}^{29}$ & 4 & Hematology/oncology & $3,5,12$, and 13 & & $\begin{array}{l}\text { Insulated container } \\
\text { in a }-80^{\circ} \mathrm{C} \text { freezer }\end{array}$ & DMSO \\
\hline 2011 & $\begin{array}{l}\text { Sadri-Ardekani } \\
\text { et al }{ }^{32}\end{array}$ & 2 & Oncology & 6.5 and 8 & Tissue & CRF & DMSO \\
\hline 2011 & Wyns et $\mathrm{al}^{45}$ & 62 & Hematology/oncology & $<12$ and $12-16$ & Tissue & CRF & DMSO \\
\hline 2011 & Curaba et $\mathrm{al}^{21}$ & 2 & Oncology & 6 and 12 & Tissue & $\begin{array}{l}\text { CRF and } \\
\text { vitrification }\end{array}$ & $\begin{array}{l}\text { DMSO and ethylene } \\
\text { glycol }\end{array}$ \\
\hline 2012 & Stimpfel et $\mathrm{a}^{38}$ & 6 & Azoospermia & $2|-4|$ & Tissue & CRF & Glycerol \\
\hline 2012 & Van Saen et a ${ }^{48}$ & 7 & Klinefelter syndrome & $13-16$ & Tissue & $\begin{array}{l}\text { Insulated container } \\
\text { in a }-80^{\circ} \mathrm{C} \text { freezer }\end{array}$ & DMSO \\
\hline 2013 & Mirzapour et a ${ }^{35}$ & 8 & Infertility & $28-50$ & Isolated cells & $\begin{array}{l}\text { Insulated container } \\
\text { in a }-80^{\circ} \mathrm{C}^{\prime} \text { freezer }\end{array}$ & DMSO \\
\hline 2013 & $\begin{array}{l}\text { Pacchiarotti } \\
\text { et } \mathrm{al}^{27}\end{array}$ & 5 & $\begin{array}{l}\text { Orchiectomy } \\
\text { (transgender) }\end{array}$ & $25-40$ & $\begin{array}{l}\text { Isolated cells/ } \\
\text { tissue }\end{array}$ & CRF & $\begin{array}{l}\mathrm{PBS}+10 \% \mathrm{HSA}+10 \% \\
\mathrm{DMSO} / 1 \% \text { dextran }\end{array}$ \\
\hline 2013 & Van Saen et al ${ }^{30}$ & 6 & Hematology/oncology & $2.5-12.5$ & Tissue & $\begin{array}{l}\text { Insulated container } \\
\text { in a }-80^{\circ} \mathrm{C} \text { freezer }\end{array}$ & DMSO \\
\hline 2013 & Poels et $\mathrm{a}^{24}$ & 10 & Hematology/oncology & $2-12$ & Tissue & $\begin{array}{l}\text { CRF and } \\
\text { vitrification }\end{array}$ & $\begin{array}{l}\text { DMSO and ethylene } \\
\text { glycol }\end{array}$ \\
\hline 2013 & Baert et $\mathrm{a}^{25}$ & 14 & Vasectomy reversal & N/A & Tissue & $\begin{array}{l}\text { Slow Freezing } \\
\text { container, CRF, and } \\
\text { vitrification }\end{array}$ & $\begin{array}{l}\text { DMSO and ethylene } \\
\text { glycol }\end{array}$ \\
\hline 2014 & $\begin{array}{l}\text { Nickkholgh } \\
\text { et } \mathrm{al}^{33}\end{array}$ & 2 & $\begin{array}{l}\text { Orchiectomy (prostate } \\
\text { cancer) }\end{array}$ & N/A & Tissue & $\begin{array}{l}\text { Insulated container } \\
\text { in a }-80^{\circ} \mathrm{C} \text { freezer }\end{array}$ & DMSO \\
\hline 2014 & Zheng et $\mathrm{a}^{37}$ & 9 & $\begin{array}{l}\text { Orchiectomy (brain dead } \\
\text { donors) }\end{array}$ & $13-40$ & Tissue & $\mathrm{N} / \mathrm{A}$ & DMSO \\
\hline 2014 & $\begin{array}{l}\text { Nickkholgh } \\
\text { et a }\left.\right|^{34}\end{array}$ & 2 & $\begin{array}{l}\text { Orchiectomy (prostate } \\
\text { cancer) }\end{array}$ & N/A & Tissue & $\begin{array}{l}\text { Insulated container } \\
\text { in a }-80^{\circ} \mathrm{C} \text { freezer }\end{array}$ & DMSO \\
\hline 2015 & Pietzak et $\mathrm{al}^{44}$ & 27 & Hematology/oncology & $2.2-11.5$ & Tissue & CRF & DMSO \\
\hline 2015 & Baert et $\mathrm{al}^{40}$ & 6 & $\begin{array}{l}\text { Vasectomy reversal/ } \\
\text { orchiectomy (prostate } \\
\text { cancer) }\end{array}$ & N/A & Tissue & $\begin{array}{l}\text { Slow freezing } \\
\text { container }\end{array}$ & DMSO \\
\hline 2016 & $\begin{array}{l}\text { Sadri-Ardekani } \\
\text { et al }{ }^{47}\end{array}$ & 23 & Oncology/cryptorchidism & $\begin{array}{l}0.7-16 \text { (oncology), } \\
\text { I.4-II } \\
\text { (cryptorchidism) }\end{array}$ & Tissue & CRF (sperm, stem) & DMSO and glycerol \\
\hline 2016 & Medrano et $\mathrm{al}^{41}$ & 3 & $\begin{array}{l}\text { Orchiectomy (prostate } \\
\text { cancer) }\end{array}$ & $\mathrm{N} / \mathrm{A}$ & Tissue & $\begin{array}{l}\text { Insulated container } \\
\text { in a }-80^{\circ} \mathrm{C} \text { freezer }\end{array}$ & DMSO \\
\hline 2017 & Gat et $\mathrm{al}^{42}$ & 2 & $\begin{array}{l}\text { Orchiectomy (testicular } \\
\text { malignancy, testicular } \\
\text { pain) }\end{array}$ & 25 and 32 & Tissue & $\mathrm{N} / \mathrm{A}$ & $\begin{array}{l}\text { MEM }+20 \% \mathrm{FBS}+5 \% \\
\text { DMSO }\end{array}$ \\
\hline 2017 & de Michele et $\mathrm{a}^{49}$ & 3 & Oncology & 2,11 , and 12 & Tissue & CRF & DMSO \\
\hline 2017 & Pendergraft et al ${ }^{9}$ & 3 & $\begin{array}{l}\text { Orchiectomy (brain dead } \\
\text { donors) }\end{array}$ & $56-61$ & $\begin{array}{l}\text { Tissue, 3D } \\
\text { organoid }\end{array}$ & $\begin{array}{l}\text { Insulated container } \\
\text { in a }-80^{\circ} \mathrm{C} \text { freezer }\end{array}$ & DMSO \\
\hline
\end{tabular}

Abbreviations: CRF, control rate freezer; DMSO, dimethyl sulfoxide; FBS, fetal bovine serum; HSA, human serum albumin; MEM, minimum essential media; PBS, phosphate-buffered saline; PrOH, propane-I,2-diol; N/A, not available. 


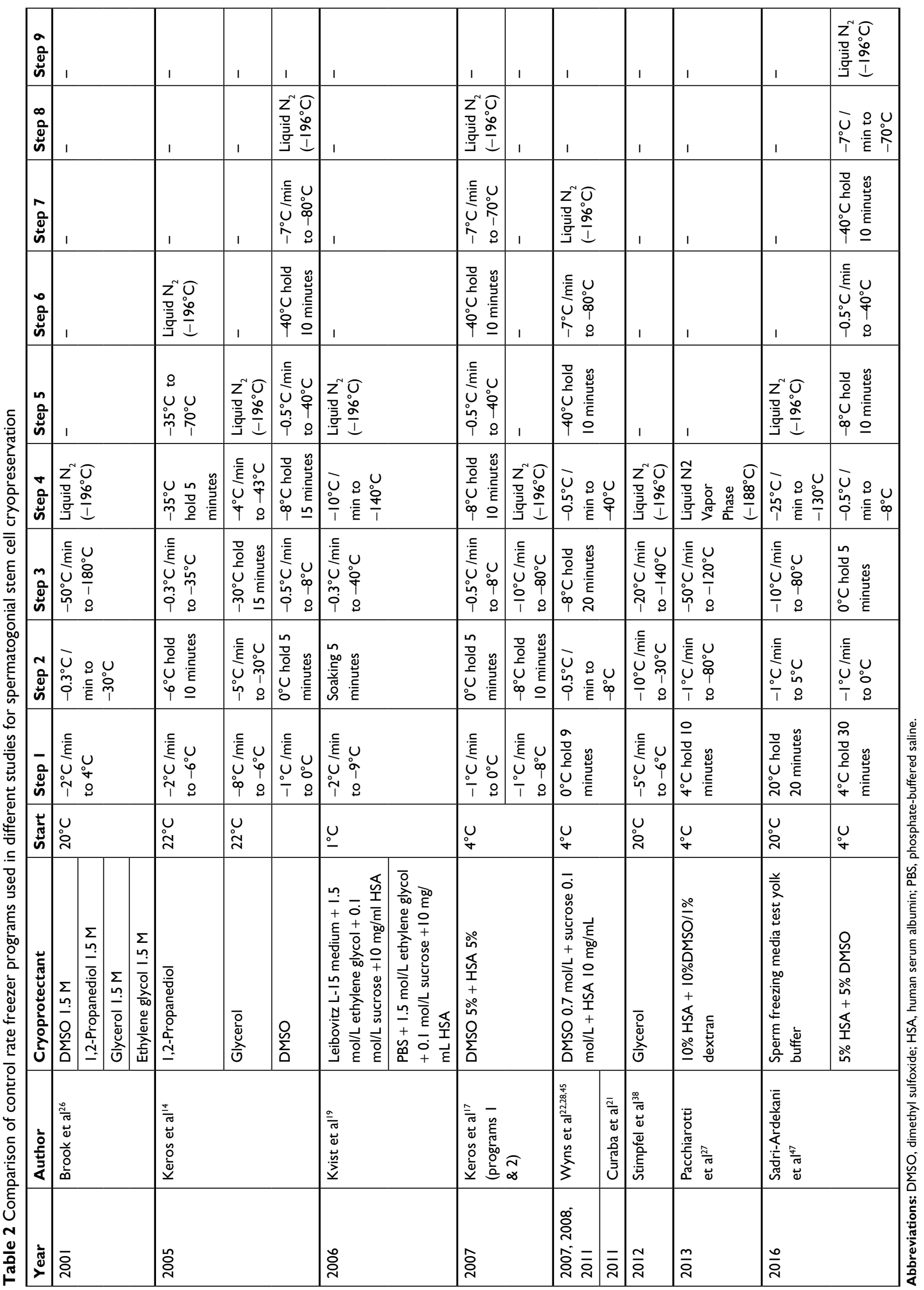


of control rate freezer (CRF, Figure 3C) programs used in different studies. We divided the articles based on their focus into four categories:

1. Optimal cryoprotectant and methods, in which researchers focused on finding the best medium and protocol for either tissue or cell cryopreservation by comparing different conditions;

2. SSCs after cryopreservation, which includes studies using cryopreserved testicular tissue to isolate and culture cells, especially SSCs, and to propagate and characterize them using different methods;

3. Experimental testicular tissue banking, as an important clinical aspect of tissue cryopreservation and its indications;

4. Experimental applications of cryopreserved testicular tissues including in vitro differentiation and transplantation of SSCs.

\section{Optimal cryoprotectant and methods} Tissue cryopreservation (slow freezing)

In 2000, Bahadur et al did the very first trial to freeze testicular tissue using three different cryopreservative media: 1) an egg-yolk-based medium containing glycerol; 2) in vitro fertilization (IVF) medium supplemented with glycerol and serum; and 3) phosphate-buffered saline (PBS) containing propane-1,2-diol (PrOH) and sucrose. ${ }^{13}$ Testicular biopsy was performed on one testicle only in two boys, 8 and 13 years old, who were diagnosed with Ewing sarcoma and Hodgkin's lymphoma, respectively. Tissue and medium were placed in nitrogen vapor phase for 1.5 hours with a cooling rate of $10^{\circ} \mathrm{C} / \mathrm{min}$ and then plunged into liquid nitrogen (LN2). A small segment was preserved for histological analysis in Bouin's solution. While they did histological evaluation on both tissues before cryopreservation using Bouin's fixed samples, this study lacks any comparison between the three cryoprotectants and any post-thaw evaluations.

Later in 2005, Keros et al compared three different protocols on adult testicular tissue using CRF to find an optimum cryoprotectant. ${ }^{14}$ They used 1) egg-yolk-based medium containing $12 \%$ glycerol routinely used for semen cryopreservation; 2) 1.5 M PrOH; and 3) 0.7 M DMSO, which were previously used for cryopreservation of ovarian and fetal testicular tissues, respectively. ${ }^{15,16}$ Using light and transmission electron microscopy (TEM), they compared the three conditions versus a fresh tissue in terms of morphological preservation and reported that DMSO preserved a testicular tissue with a better morphological structure than in the other two conditions, compared with the fresh tissue (DMSO, 70 $\pm 6 \%$; fresh, $86 \pm 6 \%$; PrOH $37 \pm 3 \%$; and glycerol, almost $0 \%$ ). They also evaluated the percentage of detached spermatogonial cells from basal lamina as a marker of tissue destruction, using immunohistochemistry (IHC) for MAGEA4, a specific antigen for spermatogonia in human testis tissue, and found that DMSO was the least harmful among the three other cryoprotectants compared with the fresh tissue (fresh, 1.4\%; DMSO, 2.2\%; $\mathrm{PrOH}, 7.9 \%$; and glycerol, $88 \%$ ). This study also showed higher in vitro testosterone production in DMSO group compared with $\mathrm{PrOH}$ group during a 12-day ex vivo culture, suggesting a better survival of Leydig cells in DMSO. As this study showed DMSO as an appropriate cryoprotectant for testicular tissue freezing, 2 years later, the same group compared two different CRF programs using DMSO-based medium (programs 1 and 2; Table 2) in a setting for banking testicular tissue from boys before gonadotoxic treatments. ${ }^{17}$ This time, they used 5\% DMSO and 5\% human serum albumin (HSA) diluted in Hanks' balanced salt solution (HBSS) as a cryoprotectant and compared the histological finding of five prepubertal and peripubertal testicular tissue biopsies versus fresh and 24-hour ex vivo cultured fresh tissues. CRF program 1 was longer with more holding steps and was originally designed for adult human testicular tissue cryopreservation, ${ }^{14}$ while program 2 had been used for cryopreservation of fetal testicular tissue. ${ }^{15}$ Although no major structural difference was observed between fresh, fresh/cultured, and frozen-thawed tissues in light microscopy investigation, TEM imaging showed better preservation of the cells and structure in the samples frozen in program 1. Moreover, by using IHC for MAGE-A4, Vimentin, and CD34, they were able to evaluate spermatogonial, Sertoli, and testicular stroma cells (peritubular cells), respectively. Lower numbers of spermatogonia were visualized in program 2 samples, whereas no sign of damage to the testicular network was observed in all study groups. These two studies mark the first significant comparison between different cryoprotectant and freezing programs for testicular tissue. Putting them together, the data suggest DMSO as an optimum cryoprotectant, and the slower the freezing procedure, the better the structural preservation of the tissue and the more spermatogonial cells.

Since boys with undescended testes (UDT) are at a risk of infertility in adult life despite having early orchiopexy, ${ }^{18}$ Kvist et al assessed the presence of Leibovitz L-15 in cryopreservation medium for testicular tissue by obtaining biopsies from eight boys undergoing orchiopexy surgery. ${ }^{19}$ Each biopsy sample was divided into six pieces: one was used for 
fixation and one for ex vivo culture (both served as controls), and the rest were frozen using two different cryoprotectants (two cryotubes per condition), one containing Leibovitz L-15 medium supplemented with 1.5 M EG, $0.1 \mathrm{M}$ sucrose, and 10 $\mathrm{mg} / \mathrm{mL}$ HSA and the second one containing PBS instead of Leibovitz medium. After 10 minutes of equilibration at $2^{\circ} \mathrm{C}$, the samples were frozen using a programmable freezer (Table 2) and then kept in LN2. After thawing, one piece was fixed, and the other one was cultured in supplemented Dulbecco's Modified Eagle Medium with nutrient F12 (DMEM/F-12) medium for 2 weeks in $5 \% \mathrm{CO}_{2}$ at $34^{\circ} \mathrm{C}$. Morphological evaluations revealed that immature human testes tissues maintained their structural characteristics after cryopreservation and thawing. In addition, immunostaining using c-kit (CD117) as a spermatogonial marker showed the survival of c-kit-positive germ cells in fresh and frozen-thawed tissues; however, no quantification was done to compare the two conditions. The assessment of Leydig and Sertoli cell functionality was done by collecting the medium to measure testosterone and inhibin-B levels, which revealed no significant differences. Although Leibovitz medium, which supports the growth of primary explants of embryonic cells, could potentially be a better cryoprotectant, this study proved no significant difference between using this medium and using PBS. However, the survival of spermatogonia after cryopreservation indicated a potential option for UDT patients to store their spermatogonial cells for later use.

\section{Tissue cryopreservation (vitrification)}

As vitrification has become more common in the field of assisted reproductive technology (ART) and has been shown to avoid crystal formation and ensuing freeze injuries in other tissues, ${ }^{20}$ researchers also tried to use this method to cryopreserve testis tissue. Curaba et al compared 1) vitrification (V) and 2) CRF for immature human testicular tissue to determine whether the yield of spermatogonial cells can be improved after thawing. ${ }^{21}$ In this study, they obtained testicular tissue from two cancer patients before starting chemotherapy, and pieces of around $3 \mathrm{~mm}^{3}$ were cryopreserved by both the methods. For the CRF method, they followed Wyns et al's protocol (Table 2), ${ }^{22}$ and for vitrification, they used the same protocol that had been recently developed on mouse immature testis tissue. ${ }^{23}$ Briefly, three dehydration steps were performed, and the samples were then placed on $0.3 \mathrm{~mL}$ insemination cryostraws (Figure 3D), which were cut with a scalpel and directly plunged into LN2. The cryostraws were then inserted into precooled cryovials, sealed, and stored for 24 hours in the LN2. After 24 hours of storage, they thawed the samples and cultured vitrified-warmed, CRF-thawed, and fresh tissues in a medium containing follicle stimulating hormone (FSH) for 10 days. Using hematoxylin and eosin (H\&E) and immunostaining on fixed cultured tissues for spermatogonial (MAGE-A4) and proliferation (Ki-67) markers, similar morphology in both freezing methods was reported. Although they recommended vitrification as a less expensive freezing method compared with CRF, a cost analysis is needed to make such a claim, and vitrification requires more expertise compared with CRF method.

Poels et al also tried to evaluate vitrification as a potential cryopreservation method for immature testicular tissue (ITT), by comparing three experimental groups of grafted human testes tissue to the scrotum of castrated nude mice: 1) vitrified-thawed tissue; 2) slow frozen-thawed tissue; and 3 ) fresh tissue. ${ }^{24}$ The slow freezing method consisted of a CRF program (Table 2) and a medium containing 0.7 M DMSO and $0.1 \mathrm{M}$ sucrose as cryoprotectants. For vitrification, a solution containing $15 \% \mathrm{EG}, 15 \% \mathrm{DMSO}$, and $0.5 \mathrm{M}$ sucrose in L-15 medium supplemented with $25 \mathrm{mg} / \mathrm{mL}$ HSA was used, and then, the tissue was put on cryostraws and stored in LN2. Six months after grafting, they compared the three experimental groups with fixed control tissue before xenografting by performing $\mathrm{H} \& \mathrm{E}$ staining and IHC staining using MAGE-

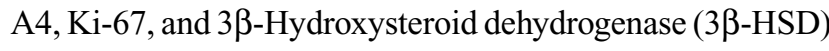
as markers for spermatogonial cells, cell proliferation, and Leydig cells, respectively. The results showed no significant differences between fresh, slow frozen-thawed, and vitrifiedthawed xenografted tissues regarding intratubular proliferative activity of cells. Double staining with MAGE-A4 and Ki-67 revealed $4 \%, 5.5 \%$, and $4.1 \%$ of spermatogonial cells showing proliferative activity, respectively. However, there was a marked decrease in the number of spermatogonial cells per tubules in all three experimental groups compared with nongrafted fresh control tissues $(<10 \%)$. These findings may be due to both cryopreservation and xenografting individually or when combined.

In another work, Baert et al reported a study using adult testicular tissue from 14 vasectomy reversal patients. ${ }^{25}$ They compared two different concentrations of DMSO (0.7 and $1.5 \mathrm{M}$ ) by using uncontrolled rate freezing (URF) and CRF methods (Table 2), in addition to comparing two vitrification methods, namely solid-surface vitrification (SSV) and direct cover vitrification (DCV). For SSV, the tissue pieces were transferred to an aluminum floater partially immersed in LN2 to allow vitrification. For DCV, the tissue fragments were immediately put in a cryovial and directly exposed to LN2. After thawing, samples from all groups were fixed for 
further light microscopy or TEM evaluation and compared with fresh tissue used as control. In all conditions, $\geq 60 \%$ of tubules stayed intact after freeze-thaw with 1.5 M DMSO in URF showing the best integrity; however, the number of UCHL1+ spermatogonia was decreased (up to 50\%) except in 1.5 M DMSO in URF, which retained similar numbers to the fresh tissue. Minimum and maximum damages in the ultrastructure of spermatogonial cells were reported in SSV and 0.7 M DMSO with CRF, respectively. Considering these results, although vitrification led to minimum ultrastructural damage of spermatogonial cells, DMSO freezing yielded more spermatogonial cells. As vitrification is a more complicated procedure, DMSO slow freezing showed more promising preservation of testicular tissue when compared with vitrification.

\section{Cells cryopreservation}

While some groups were focusing on cryopreservation of whole testicular tissue, Brook et al tried to cryopreserve isolated cells from testicular tissue with four different cryoprotectants. ${ }^{26}$ They acquired testicular tissue biopsies from five adult patients, cut them into small pieces, and incubated with collagenase for 12-20 minutes followed by trypsinEDTA medium to make a cell suspension. A total volume of $1 \mathrm{~mL}$ freezing medium was prepared containing $4 \%$ fetal bovine serum (FBS) plus $1.5 \mathrm{M}$ of each of the four following cryoprotectant reagents: DMSO, PrOH, EG, and glycerol, in four cryotubes for each cell suspension (Table 2). After 8 days, the samples were thawed, and the mean viability of cells was between $52 \%$ and $58 \%$, compared with $66 \%$ just before freezing, with no significant difference between different cryoprotective reagents. Although they tried to compare the cryoprotectants by measuring the viability of frozen-thawed cells, more specific analysis regarding different cell types, especially spermatogonia, was expected. In addition, this study did not evaluate the growth ability of cells in culture after freeze-thaw with each cryoprotectant.

Over a decade later, Pacchiarotti et al used testicular tissue of five sexual reassignment (transgender) patients who underwent hormone therapy for a period of 6-12 months prior to orchiectomy. ${ }^{27}$ The cells were isolated from tissues, and part of the tissue from each patient was frozen using PBS-based medium containing 10\% HSA, 10\% DMSO, and 1\% dextran followed by a slow freezing protocol in a CFR (Table 2). The cryotubes were quickly transferred to a validated Chart MVE BioMedical, GA, USA and stored in the vapor phase of LN2 at $-188^{\circ} \mathrm{C}$. Average viability of cells isolated from fresh tissues was $>90 \%$, which declined to $74 \%$ when isolated from frozen-thawed tissue. Moreover, the viability of the cells that were isolated from fresh tissue, cryopreserved, and then thawed decreased to $52 \%$. While their total recovery rate of viable cells from frozen tissue was one third of the rate for the fresh tissue, flow cytometry analysis showed enrichment of SSEA4+ and LHR+ cell populations after freeze-thaw of the tissue, indicating more spermatogonial and Leydig cells survived, respectively. However, the fact that these patients underwent hormonal therapy before orchiectomy could alter the behavior of their testicular tissues and cells and was not considered in this study. From both studies, we learned that cryopreservation of isolated cells from fresh tissue leads to lower cell viability after freeze-thaw, and more importantly, the isolation of cells prior to cryopreservation will deprive patients from the potential treatment options that require the whole testicular tissue (Figure 1). These all together emphasize that tissue cryopreservation is preferred over cell cryopreservation.

\section{SSCs after cryopreservation}

SSCs are the most important cell types in the testicle, responsible for preserving the spermatogonial pool of the testes to produce sperms. Viability and functionality evaluation of stored SSCs is important, depending on the freezing methods and the type of cryoprotectant. Morphological evaluation using light microscopy, TEM, and IHC and spermatogonial quantity using flow cytometry for specific spermatogonial markers have been used to assess the presence and integrity of these cells before and after cryopreservation. Other methods including xenografting the tissue and transplanting the cells retrogradely into the seminiferous tubules were also performed by researches in the field as ways of analyzing the presence and function of these cells.

\section{Xenografting}

Wyns et al in 2007 and 2008 reported two studies regarding the evaluation of cryopreserved tissues after xenografting. ${ }^{22,28}$ In the first report, they assessed survival and proliferation of spermatogonial and Sertoli cells after whole tissue cryopreservation using a modified protocol developed earlier by Keros et al ${ }^{14}$ on ITT. ${ }^{22}$ They acquired testicular biopsies from prepubertal boys undergoing unilateral orchiopexy for the treatment of cryptorchidism. Biopsies from each individual were divided into two portions; the smaller portion was fixed as control before freezing, and the larger portion was frozen in DMSO-based medium (0.7 M) supplemented with sucrose $(0.1 \mathrm{M})$ and HSA $(10 \mathrm{mg} / \mathrm{mL})$ using a programmable freezer (Table 2). After thawing, a piece of thawed human testicular 
tissue (1-6 $\left.\mathrm{mm}^{3}\right)$ was grafted into the scrotum of a mouse after removing both mouse testes at the same surgery. Three weeks later, the mice were euthanized, and tissue morphology was evaluated by H\&E staining and light microscopy using a semi-quantitative method described earlier by Keros et al, ${ }^{14}$ comparing the tissues with their controls before freezing. Integrity of the tubules was well preserved in grafted frozenthawed tissue, and in terms of morphometry, the transplantation of cryopreserved tissue did not induce any fibrosis or sclerosis. IHC for MAGE-A4, Vimentin, and Ki-67 showed presence and proliferation of spermatogonial and Sertoli cells, respectively, after cryopreservation and xenografting. A significant increase in cell proliferation, mostly Sertoli cells, was observed in grafted tissue compared with fresh tissue, and while a significant decrease was reported in the number of MAGE-A4 spermatogonia compared with fresh tissue, the percentage of proliferating spermatogonial cells was significantly higher in grafted tissue. They reported similar numbers of Sertoli cells in both conditions.

The same research group in 2008 reported long-term survival, proliferation, and differentiation of spermatogonial cells after cryopreservation of immature human testicular tissues. ${ }^{28}$ They obtained tissues from a single testicle of five boys, cryopreserved them using the same protocol in their previous work. ${ }^{22}$ After 2-12 months, tissues were thawed and transplanted to the scrotums of 6-week-old castrated mice, and after 6 months (compared with 3 weeks in the previous study), they recovered the grafted tissue for evaluation. Histological examination showed that $55 \%$ of seminiferous tubules were intact in frozen-thawed grafted tissues compared with fresh tissue $(100 \%)$, while the most extensive tubular damage $(78.2 \%$ of tubules) was observed in the two oldest boys (14 years old), in whom focal spermatogenesis was observed at the time of biopsy. Using H\&E staining and high-magnification microscopy (up to $400 \times$ ), premeiotic spermatocytes were found in grafted tissues from all three immature boys (aged 7, 12, and 12 years), but occasionally and only in one of the 12 -year-old grafted tissues, they found spermatocytes in prophase of the first meiotic division. Qualitative ultrastructural evaluation using TEM showed no damage in spermatogonial cells after freezing and grafting, and Sertoli and Leydig cells were described as normal. Immunostaining showed a significant decrease in the number of spermatogonial cells per tubule in frozen-grafted tissues compared with fresh tissue; however, double immunostaining of Ki-67 and MAGE-A4 revealed that more than one third of spermatogonial cells in frozen-grafted tissue preserved the ability to proliferate even after 6 months. IHC for $3 \beta$-HSD showed the presence of active Leydig cells, but no quantitative assessment was reported. No germ cell apoptosis in grafted tissue was observed using terminal deoxynucleotidyl transferase-mediated deoxyuridine triphosphate nick end labeling (TUNEL). Although spermatid-like cells were seen in H\&E staining of grafted tissue from all donors, IHC for meiotic and postmeiotic germ cell markers such as $\mathrm{LDH}-\mathrm{C}, \mathrm{ACE}$, and proacrosin showed no expression in frozengrafted tubules, indicating that these spermatid-like cells are not expressing markers of normal spermatids. To search for any sperm produced by the immature tissues during this time, the grafts were harvested, and testicular sperm extraction (TESE) was performed in three of them. No sperm was found in any of them after tissue freezing-thawing and grafting for 6 months.

These two studies, accompanying other studies, showed that human spermatogonial cells are able to maintain and keep proliferation ability after cryopreservation and grafting, although the spermatogonia population decreases. Normal spermatogenesis was not achieved after xenografting of frozen-thawed tissue, however.

Following Wnys' group studies, Van Saen et al in two different articles reported results of more prolonged grafting (up to 9 months) of cryopreserved testicular tissue from biopsies performed on boys undergoing chemotherapy for either cancer or bone marrow transplantation. ${ }^{29,30}$ The cryopreservation technique consisted of supplemented DMEM with $10 \% \mathrm{HSA}$, 1.4 M DMSO, and $150 \mathrm{mM}$ sucrose as cryomedium, using Mr. Frosty (Figure $3 \mathrm{~A}$ ) in $-80^{\circ} \mathrm{C}$ overnight and consequent storage in LN2. In the first study, half of one testis from each of five patients (3-13 years old) was removed, and $10 \%$ of the tissue was used for research $(90 \%$ stored for future clinical use). ${ }^{29}$ After thawing the tissues, histological integrity of the seminiferous tubules and germ cell survival rate (evaluated by $\mathrm{H} \& \mathrm{E}$ and MAGE-A4 IHC) ranged between $27 \%$ and $48 \%$ in different samples. Despite the studies of Wyns et al, ${ }^{22,28}$ in this study, mouse testes were not castrated, and human testis tissue was grafted under the tunica albuginea (after removing the same amount of mouse testis tissue to have enough space for inserting human tissue). The grafted fresh and frozen-thawed tissues were compared after 4 and 9 months. In general, the number of surviving MAGE-A4+ spermatogonial cells decreased over time in grafted tissues after 4 and 9 months. Spermatocytes and meiotic activity (Boll+ cells) could only be observed in frozen-thawed grafted tissues of the oldest patients (12 and 13 years old), which had been noted to be already differentiated to this level prior to grafting. More tubular sclerosis was observed, especially in frozen-thawed grafts, in the older patients. Lower cell survival and lack of differentiation in the younger patients in this study could 
also be caused by the previous chemotherapy received prior to performing the biopsy.

The same group, in a follow-up study, obtained human testicular tissue from six patients aged $2.5-12.5$ years. ${ }^{30}$ The cryopreservation process and grafting were performed in the same exact manner they described in $2011 .{ }^{29}$ However, this time, the grafted tissues were evaluated over longer time periods (9-12 months), and the transplanted mice were divided into two groups: with and without subcutaneous injection of FSH three times per week until graft excision. Although less tubular integrity was observed in frozenthawed grafts compared with fresh tissue, no significant differences were found between untreated and FSH-treated frozen-thawed grafts (average 65\% integrity). Higher percentage of MAGE-A4+ tubules survived in both fresh tissue grafts in both FSH-treated and untreated groups when compared to frozen-thawed grafts. Fewer spermatogonia survived in treated groups, but no statistical significance was noted. Unlike the previous study, differentiation up to pachytene spermatocyte level was observed in grafts from older patients as well as younger boys. Differentiation was found in the untreated grafts as well as in the FSH-treated grafts; however, the expression of meiotic activity (Boll+ cells) was only found in the untreated testicular graft from the 12.5-year-old patient. As noted previously, some patients in this study had already received chemotherapy, making interpretation of the conclusions difficult.

These studies suggest that xenografting not only can be used to evaluate cryopreserved tissue, but also could be one of the potential options in the future to create sperms for intracytoplasmic sperm injection (ICSI) (Figure 1-IV).

\section{Cell isolation and in vitro propagation}

A landmark study by Sadri-Ardekani et al was the first to report successful long-term ( $>6$ months) in vitro propagation of SSCs from frozen-thawed adult testes tissue. ${ }^{31}$ They used minimum essential media (MEM) supplemented with $20 \%$ FBS and $8 \%$ DMSO to cryopreserve testicular tissue from six prostate cancer patients undergoing orchiectomy. The tissue was frozen using Nalgene ${ }^{\circledR}$ Cryo $1^{\circ} \mathrm{C}$ "Mr. Frosty" (Thermo Fisher Scientific, Waltham, MA, USA; Figure 3A). The freezing container was placed overnight inside a $-80^{\circ} \mathrm{C}$ freezer $\left(-1^{\circ} \mathrm{C} /\right.$ minute cooling rate $)$, and cryotubes were transferred to $-196^{\circ} \mathrm{C}$ (liquid $\mathrm{N}_{2}$ ) the following day. After a few months, the tissues were thawed and testicular cells were isolated, propagated, and cultured in supplemented Stem-Pro 34 medium at $37^{\circ} \mathrm{C}$ and in $5 \% \mathrm{CO}_{2}$ up to 28 weeks. Clusters of germ line stem cells as well as embryonic stem cell-like colonies appeared, and the presence of spermatogonial cells during the culture was confirmed by reverse transcriptase polymerase chain reaction (RT-PCR) and immunofluorescent staining using specific markers including PLZF/ZBTB16, ITGA6, and ITGB1. They also transplanted frozen-thawed cultured cell to nude mice testes to confirm the presence of functional SSCs. In a follow-up study in 2011, the same research group showed successful in vitro propagation of human SSCs from cryopreserved prepubertal testicular tissue. ${ }^{32}$ This time, biopsy specimens were taken from two boys diagnosed with Hodgkin lymphoma and cryopreserved in a medium containing 5\% DMSO and 5\% HSA following the same method as in Keros et al $2007^{17}$ using CRF (Table 2). After thawing, the cells were isolated with the same twostep enzymatic digestion and culture process described in their previous study. ${ }^{31}$ To confirm the presence of functional SSCs, cultured cells were transplanted into the testes of busulfan-treated immune deficient mice, and after 8 weeks, SSCs were detected on the basal membrane of mouse seminiferous tubules. These two studies were the first to isolate and propagate SSCs from human testicular tissue to a number that might be enough for autotransplantation, showing promising potential for testicular tissue banking for boys at a risk of infertility.

In 2014, Nickkholgh et al presented two different studies assessing SSC functionality and stability in culture using frozen tissue. ${ }^{33,34}$ Cryopreserved testicular tissues were obtained from patients undergoing orchiectomy as part of their prostate cancer treatment. The cryomedium was MEM based with $20 \% \mathrm{FBS}$ and $8 \%$ DMSO. The tissue was frozen manually using Mr. Frosty and then stored at $-180^{\circ} \mathrm{C}$. In the first study, after thawing the tissue, germ cells were isolated and propagated in culture for 50 days. ${ }^{33}$ They were then sorted by magnetic-assisted cell sorting for ITGA6+ and HLA.ABC-/ GPR125+ and were transplanted into nude mouse testes. Tracking transplanted cells using Cot-1 human DNA fluorescence in situ hybridization probe showed 7.1- and 3.9-fold increase in the population of SSCs in sorted and nonsorted transplanted cultured cells, respectively. In 15 of 19 (79\%) recipients' testes, human SSC colonies were observed indicating similar behavior to freshly isolated noncultured human SSCs, suggesting that long-term cultured SSCs do not lose the ability to migrate and self-renew after xenotransplantation. In their second study, to investigate the genomic stability of human spermatogonia during in vitro propagation, an array comparative genomic hybridization was performed on single cells from noncultured and cultured ITGA6-sorted testicular cells. ${ }^{34}$ All karyotyped cultured cells from both patients (13 
cells per patient) were euploid, ie, 46, XY. Moreover, methylation status of $\mathrm{CpG}$ islands in paternally and maternally imprinted genes of the cells sorted for ITGA6 after 50 days of culture showed demethylation of paternally imprinted genes and increased methylation of maternally imprinted genes. In the future, whole epigenome study of in vitro propagated SSC and culture system improvements are required. It is also likely that the epigenome changed after SSC transplantation as cells come back to their natural niche.

Mirzapour et al evaluated the effects of cryopreservation on SSC population and propagation of frozen-thawed SSCs during culture. ${ }^{35}$ They obtained testicular biopsies from patients who were diagnosed with maturation arrest of spermatogenesis. Testicular cells were isolated by a two-step enzymatic digestion, and the cell suspension was divided into two groups, one for cryopreservation and the other for culture for 2 weeks using monolayers of Sertoli cells as a supporting system. For cryopreservation, they followed a modified protocol of Izadyar et al used for calves, ${ }^{36}$ including DMEM containing $10 \%$ DMSO, $10 \%$ FBS, and $0.07 \mathrm{M}$ sucrose as cryopreservation medium. Then, the cryotubes were placed in an insulated container in $-80^{\circ} \mathrm{C}$ freezer for a day before transferring to LN2. The frozen-thawed spermatogonial cells were cultured for 2 weeks before freezing for three more weeks in two different groups with fresh Sertoli cells (experimental group 1) and frozen-thawed Sertoli cells (experimental group 2 ), comparing each with freshly isolated spermatogonial cells cultured on fresh Sertoli cells as control. By assessing the diameter and number of colonies every week and IHC staining of the colonies for cadherin type 1, Oct-4, Vimentin, and alkaline phosphatase activity, significantly higher numbers and larger diameters were found in colonies in experimental group 1 compared with group 2 and the control group, suggesting enrichment of spermatogonial cell populations after freeze-thaw. This suggests that SSCs are more resistant to low temperature than other types of testicular cells.

To validate multiple assays for the characterization of testicular cultures, Zheng et al followed the procedure described by Sadri-Ardekani et a ${ }^{31}$ to culture isolated cells from cryopreserved testicular tissue in a FBS-based cryomedium containing $10 \%$ DMEM and $10 \%$ DMSO.${ }^{37}$ The average yield of the isolated cells from the frozen-thawed samples was around $25 \%$ of the yield from fresh tissue. Flow cytometry analyses showed that in early culture (7 days) up to $30 \%$ of cells were SSEA4+; however in later time points, the value declined to $<0.8 \%$ SSEA4+ cells, indicating somatic cells becoming more confluent.
Stimpfel et al cryopreserved testicular tissue from six adult patients with azoospermia who had no sperm observed in the tissues under TESE procedure. ${ }^{38}$ Their cryopreservation method consisted of flushing medium enriched with $20 \%$ glycerol and freezing by CRF (Table 2 ). While DMSO as an appropriate cryoprotectant was almost established by different research groups before this study, glycerol use was not an optimum choice in this study. After thawing, testicular cells were mechanically and enzymatically isolated from the tissues following the procedures described previously, ${ }^{31,39}$ with a final viability of $60 \%$. The isolated cells were cultured in two different media: 1) DMEM-F12 with 20\% FBS and 2) DMEM-F12 with 20\% follicular fluid, which was retrieved at oocyte aspiration for IVF, up to 114 days. Markers such as CD9, KLF4, and UTF1 were present in isolated cells, which was found by using RT-PCR and flow cytometry analysis, and this study reported $2 \%$ SSEA+ cells at day 80 of in vitro culture.

Baert et al compared the viability and characterization of cells isolated from fresh and cryopreserved tissues in MEM-based medium contained 20\% FBS and 8\% DMSO using an insulated container. ${ }^{40}$ No substantial difference was found between the fresh and frozen groups, and although the population of the UCHL1+/VASA+ spermatogonial decreased over time in culture, they ultimately resulted in the same range in both conditions (initially $3.4 \%-8 \%$, after 1 month $7.3 \%$, and after 2 months $0.8 \%-1.6 \%$ ). This suggests that the cryopreservation method could maintain similar tissue dynamics as their fresh controls.

In a recent study, Medrano et al cultured isolated testicular cells from testicular tissues frozen from three prostate cancer patients. ${ }^{41}$ For cryopreservation, the biopsies were cut into small fragments and frozen slowly in DMEM-Ham's F12 medium with $10 \%$ FBS, $0.15 \mathrm{M}$ sucrose, and 1.5 M DMSO. The cells were isolated from thawed tissues and cultured as previously described in mouse ${ }^{39}$ and human, ${ }^{31}$ with and without differential plating (named as "traditional culture"). To avoid overgrowing of somatic cells, in some experiments, they cultured sorted HLA.ABC-/EPCAM+ germ cells using fluorescence-activated cell sorting (FACS) on mitotically inactivated testicular feeder cells from the same patient aiming at finding an optimum culture condition for SSCs. Population of VASA+/UTF1+ (enriched for SSCs) at day 14 was statistically higher $\left(112 \mathrm{cells} / \mathrm{cm}^{2}\right)$ in FACS-sorted cultured cells compared with traditional methods (62 and 49 cells $/ \mathrm{cm}^{2}$ in cultures without and with differential plating, respectively). However, these SSC-enriched populations 
decreased significantly until almost disappearing in day 28 of culture in all conditions.

Gat et al obtained testicular tissues from two patients and froze them in small pieces using MEM-based medium with $20 \%$ FBS and 5\% DMSO. ${ }^{42}$ To compare the behavior of human testicular cells in different culture conditions, the cells were isolated and cultured in two different enriched media: 1) StemPro-34 and 2) DMEM-F12, both containing $2 \%$ FBS. Total population doubling time was significantly higher in DMEM-F12 (320 hours), representing a lower proliferation rate compared with StemPro-34 (120 hours), while cell morphology in both cultures was similar and population of CD90+ cells (representative of somatic cells) increased in both conditions over time. However, they observed more germ cell-like aggregates in DMEM-F12, twice as many as in StemPro culture, suggesting that DMEM-F12 is a more suitable medium for germ cell propagation. More characterization and functional studies are required to compare these two culture mediums in terms of SSC propagation.

\section{Experimental testicular tissue banking and its indications}

As we discussed about different cryopreservation methods for testicular tissue and subsequent SSC isolation and culture from cryopreserved tissue in different aspects, an important clinical application of this field is testicular tissue banking. Sperm cryopreservation is not available for prepubertal boys in cases of gonadotoxic diseases or treatments; therefore, testicular tissue cryopreservation containing SSCs for future fertility preservation is the only potential option now. Here, we summarize articles regarding testicular tissue banking programs in which they describe their freezing methods and indications for banking.

Ginsberg et al created an experimental protocol for cryopreserving human testicular tissues from boys newly diagnosed with cancer. ${ }^{43}$ A $40 \mathrm{~mm}^{3}$ specimen was cryopreserved following the methods described by Keros et $\mathrm{al}^{17}$ and Wyns et al, ${ }^{22}$ using 5\% DMSO as a cryoprotectant with a slow programmable freezer (Table 2). No intraoperative or postoperative adverse events were reported after a week from the testicular biopsy. Later, Pietzak et al then evaluated the histology of these testes using a small portion of testicular tissue fixed in $2 \%$ glutaraldehyde and embedded in bisphenol, a diglycidyl ether epoxy resin. ${ }^{44}$ These semi-thin $0.4-\mu \mathrm{m}$ sections were then stained with toluene blue. Among 27 children, they reported that 22 children $(81.5 \%)$ had normal germ cells per tubules for age, while the remaining five children (18.5\%) had increased germ cell counts. However, details of cell count have not been described in this study, and histology methods used are not usually available in most clinical departments.

Wyns et al summarized their fertility preservation program for boys at a risk of gonadotoxic treatments. ${ }^{45}$ Following their previous studies, they established a banking protocol and cryopreserved testicular tissue from pediatric patients in the period of 2005-2010 prior to undergoing chemotherapy. Only one testis was biopsied in each child, and $<5 \%$ of the testicular volume was removed. As cryomedium, $0.7 \mathrm{M}$ DMSO supplemented with $0.1 \mathrm{M}$ sucrose and $10 \mathrm{mg} / \mathrm{mL}$ HSA solutions was used. Depending on the age of the patient, one or two different control freeze programs were used: ITT protocol to cryopreserve spermatogonia in all the patients and mature testicular tissue protocol to cryopreserve gametes ${ }^{46}$ in peripubertal patients ( $\geq 12$ years old), as there was a chance of obtaining differentiated germ cells (Table 2). Evaluation by H\&E and IHC for MAGE-A4 confirmed the presence of spermatogonial cells in all ages in this study. Interestingly, they reported that $10 \%$ of patients suffered from benign pathologies such as anemia, beta-thalassemia, and chronic granulomatous disease, but they were still undergoing treatments compromising germ cells in the testes, suggesting more indications for banking.

In another approach utilizing testicular tissue banking to preserve SSCs for potential future long-term fertility usage, Sadri-Ardekani et al introduced an experimental protocol for testicular tissue banking by collecting biopsies from both testes of prepubertal boys having either cancer or bilateral UDT. ${ }^{47}$ Cryopreservation technique was determined by whether sperms were seen in the tissue or not. Therefore, two different media were used, either commercial sperm-freezing medium containing glycerol or HBSS containing 5\% DMSO and 5\% HSA in case of no sperm. Freezing process was performed using a CRF (Table 2). They chose this DMSObased cryopreservation medium and CRF freezing method based on previous descriptions noting the preservation of the functionality of human SSCs from immature testis tissue after freeze-thaw, culturing, and xenotransplantation. ${ }^{32}$ Fresh tissue was fixed and evaluated by H\&E staining and IHC (double staining for MAGE-A4 for spermatogonial cells and $\mathrm{Ki}-67$ for proliferating cells), and when potential leukemia infiltration of the testis was possible, anti CD1a, CD3, or TdT IHC staining was also performed. The average number of MAGE-A4+ spermatogonial cells located on the basement membrane of each seminiferous tubule was 2.2 times higher in boys with cancer, and the percentages of proliferating spermatogonia in boys with cancer and bilateral UDT boys were 16.4 and 30.7 , respectively. These data suggest germ cell 
depletion and a compensational proliferation due to dislocation of testes in UDT boys; therefore, autotransplantation of propagated SSCs may increase the fertility ability of these patients in the future.

Another potential indication for testicular tissue banking is $\mathrm{KS}$, or the XXY condition, the most common sex chromosome abnormality in humans (1/600 live births), and is characterized by extensive fibrosis of testes and hyalinization of the seminiferous tubules after puberty. In 2011, Van Saen et al published an experimental study protocol, investigating the possibility of recovering SSCs from KS testicular tissue obtained in adolescence. ${ }^{48}$ They offered testicular cryopreservation to KS adolescents with either clinical (arrest or regression of testicular volume) or biological (serum FSH $>10 \mathrm{IU} / \mathrm{L}$ or declining serum inhibin-B) signs of testicular failure. Instead of multiple biopsies, a single large-volume biopsy was taken from the lower pole of the larger testis to reduce the risk of postoperative fibrosis. Harvested tissue was frozen according to their previous study ${ }^{29}$ by cutting the tissue into $6 \mathrm{~mm}^{3}$ fragments and using Mr. Frosty containers. Fixed tissues prior to freezing were evaluated and scored by their structural integrity and fibrosis. While interstitial fibrosis was present in all KS biopsies with very few normal tubules (range 0\%-18\%), samples from the youngest patient $(13.3$ years old) showed the least disturbed morphology with $71 \%$ of the tubules showing normal architecture. Moreover, IHCs were performed for MAGE-A4, anti-Mullerian hormone $(\mathrm{AMH})$, and inhibin-alpha, and STAR to assess the number of spermatogonia, maturation, and function of Sertoli cells and Leydig cells, respectively. The results showed the presence of spermatogonial cells in five of seven boys (72\%), and the expression of AMH was downregulated in all KS patients' testes, indicating that their Sertoli cells already started maturity. In all patients, Sertoli cells stained positive for inhibin confirming their functional activity, while STAR expression revealed Leydig cell hyperplasia in half of the patients. While this study showed $72 \%$ chance of having spermatogonia in KS patients around the age of puberty, there is still controversy among the clinicians and researchers on whether testicular biopsy should be offered to the KS patients and when the optimum time is. Hence, more research in this area is expected in the near future to evaluate the chance of having and preserving SSCs in KS patients for fertility preservation.

\section{Future applications}

While experimental testicular tissue banking is now considered a potential option for future fertility applications, no one has yet applied SSC therapy to preserve fertility in humans, despite SSC isolation and transplantation having been shown to be successful in several animal species, including but not limited to mice, dogs, and nonhuman primates. ${ }^{5,6}$ Current researches are not only focusing on SSC transplantation, but also in vitro differentiation of SSCs to functional sperms, which could potentially be an alternative for SSC culture and propagation. ${ }^{4}$ Here, we mention two recent articles that tried to achieve in vitro germ cell differentiation using cryopreserved testicular tissue.

de Michele et al cultured tissue fragments from three prepubertal boys in an organotypic culture for 139 days. ${ }^{49}$ The tissue was frozen using CRF machine and followed the protocol described in the past. ${ }^{22}$ Fragments as small as $1 \mathrm{~mm}^{3}$ were placed in an insert inside a 24-well plate well and maintained in an enriched DMEM-F12 medium supplemented either with testosterone (condition 1) or with human chorionic gonadotropin (hCG; condition 2 ) at $34^{\circ} \mathrm{C}$ in $5 \%$ $\mathrm{CO}_{2}$. In condition 1 , they increased the testosterone level in day 16 to mimic peripubertal physiology. The medium was refreshed every 48 hours. Tissue viability was preserved in both conditions during the culture period. Immature Sertoli cells became mature, confirmed by decreased proliferation activity and lower AMH production over time. The detection of MAGE-A4-positive cells at the end of culture revealed the presence of spermatogonia; however, no germ cell differentiation was observed during the culture period in any of the conditions.

Since organoid and 3D cell culture systems are emerging as pivotal models for drug screening, investigating personalized medicine and understanding human organ development, Pendergraft et al developed a novel 3D organoid system from frozen-thawed adult testicular tissue. ${ }^{9}$ Normal testicular tissues from deceased brain donors were received and cryopreserved (Table 1) using Mr. Frosty, as described by SadriArdekani et al. ${ }^{31}$ SSCs and Sertoli, Leydig, and peritubular cells were isolated from thawed tissue and propagated in two-dimensional (2D) cultures as described previously. ${ }^{31,50-52}$ Using 10,000 cells per well, primary cultured spermatogonial and peritubular cells were incorporated with immortalized Sertoli and Leydig cells in a hanging drop system to form $3 \mathrm{D}$ testicular organoids. Organoids were cultured in ultralow attachment U-bottom well plates in an enriched StemPro-34 medium containing human testis extracellular matrix up to 3 weeks. For the entire culture period, the human testis organoid produced testosterone with and without hCG stimulation. Upregulation of postmeiotic germ cell genes confirmed the differentiation of SSCs to spermatid-like cells with a 
population of around $0.2 \%$ of cells in differentiated organoids. They also investigated the feasibility of cryopreserving these organoids for long-term storage and distribution, using two methods: uncontrolled slow freezing (in MEM-based medium containing 8\% DMSO and using Mr. Frosty) and vitrification. Although the organoids seemed to be under more stress after slow freezing compared with vitrification when thawed, both conditions maintained normal morphology and viability around $90 \%$ after a short recovery period. While this study was done using adult testicular tissue, it is expected that it will be applied to prepubertal testicular tissue, improving this system to pursue in vitro differentiation from immature tissue.

\section{Conclusion}

During the past decades, several groups pursued and showed the feasibility of human testicular tissue cryopreservation from adult and immature individuals (Table 1) and proved that SSCs could also be stored and recovered after freezethaw using different methods (Figure 3; Table 2). Mouse studies showed long-term stability of frozen SSCs and normal offspring after transplantation. ${ }^{53}$ Although these findings are expected to be the same for stored human material, it is important to evaluate the quality and stability of long-term stored human testis materials and optimize ongoing banking protocols accordingly. Usually the size of testis biopsy from pediatric patients is very small, and the number of SSCs in this tissue is limited; therefore, in vitro propagation of human SSCs will be required prior to transplantation in the future. Multiple groups have been able to culture human SSCs from frozen adult testes (around 40 patients until now), ${ }^{31,33-35,37,38,40-42}$ but so far only one study (including only two patients) has shown prepubertal SSC in vitro propagation from frozen-thawed material. ${ }^{32}$ Optimization of SSC culture using stored prepubertal testis tissue and adjustment to good manufacturing practice conditions will be a crucial step before starting the first clinical trials of human SSC auto transplantation. Although some attempts have been done to find an optimum method to detect and purge cancer cells prior to SSC transplantation, ${ }^{54-58}$ additional concerns regarding potential contamination of cryopreserved testicular tissue or isolated cells with malignant cells, especially in nonsolid tumor cancer patients, will need to be addressed. The overall data indicate that frozen testicular tissue can also be utilized for varied alternative fertility preservation options including $2 \mathrm{D}$ or $3 \mathrm{D}$ in vitro spermatogenesis, ex vivo differentiation, and xenografting in the future.

\section{Disclosure}

The authors report no conflicts of interest in this work.

\section{References}

1. Watson CJ, Dark JH. Organ transplantation: historical perspective and current practice. Br J Anaesth. 2012;108(Suppl 1):i29-i42.

2. Sadri-Ardekani H, Atala A. Regenerative medicine for the treatment of reproductive system disorders: current and potential options. Adv Drug Deliv Rev. 2015;82-83:145-152.

3. Brinster RL, Avarbock MR. Germline transmission of donor haplotype following spermatogonial transplantation. Proc Natl Acad Sci U S A. 1994;91(24):11303-11307.

4. Galdon G, Atala A, Sadri-Ardekani H. In vitro spermatogenesis: how far from clinical application? Curr Urol Rep. 2016;17(7):49.

5. Sadri-Ardekani H, Atala A. Testicular tissue cryopreservation and spermatogonial stem cell transplantation to restore fertility: from bench to bedside. Stem Cell Res Ther. 2014;5(3):68.

6. Hermann BP, Sukhwani M, Winkler F, et al. Spermatogonial stem cell transplantation into rhesus testes regenerates spermatogenesis producing functional sperm. Cell Stem Cell. 2012;11(5):715-726.

7. Francipane MG, Lagasse E. Towards organs on demand: breakthroughs and challenges in models of organogenesis. Curr Pathobiol Rep. 2016;4(3):77-85.

8. Bardsley K, Deegan AJ, El Haj A, Yang Y. Current state-of-the-art 3D tissue models and their compatibility with live cell imaging. Adv Exp Med Biol. 2017;1035:3-18.

9. Pendergraft SS, Sadri-Ardekani H, Atala A, Bishop CE. Three-dimensional testicular organoid: a novel tool for the study of human spermatogenesis and gonadotoxicity in vitro. Biol Reprod. 2017;96(3):720-732.

10. Jemal A, Center MM, DeSantis C, Ward EM. Global patterns of cancer incidence and mortality rates and trends. Cancer Epidemiol Biomarkers Prev. 2010;19(8):1893-1907.

11. SEER Cancer Statistics Review, 1975-2008. Bethesda, MD: National Cancer Institute. Available from: http://seer.cancer.gov/csr/1975_2008/. Accessed March 1, 2018.

12. Wallace WH, Anderson RA, Irvine DS. Fertility preservation for young patients with cancer: who is at risk and what can be offered? Lancet Oncol. 2005;6(4):209-218.

13. Bahadur G, Chatterjee R, Ralph D. Testicular tissue cryopreservation in boys. Ethical and legal issues: case report. Hum Reprod. 2000;15(6):1416-1420.

14. Keros V, Rosenlund B, Hultenby K, Aghajanova L, Levkov L, Hovatta O. Optimizing cryopreservation of human testicular tissue: comparison of protocols with glycerol, propanediol and dimethylsulphoxide as cryoprotectants. Hum Reprod. 2005;20(6):1676-1687.

15. Keros V. Cryopreservation of human fetus testicular tissue and low temperature bank creation for further application in clinical transplantology. Prob Cryobiol. 1999;3:54-58.

16. Hovatta O, Silye R, Krausz T, et al. Cryopreservation of human ovarian tissue using dimethylsulphoxide and propanediol-sucrose as cryoprotectants. Hum Reprod. 1996;11(6):1268-1272.

17. Keros V, Hultenby K, Borgstrom B, Fridstrom M, Jahnukainen K, Hovatta $\mathrm{O}$. Methods of cryopreservation of testicular tissue with viable spermatogonia in pre-pubertal boys undergoing gonadotoxic cancer treatment. Hum Reprod. 2007;22(5):1384-1395.

18. Hadziselimovic F, Hadziselimovic NO, Demougin P, Oakeley EJ. Testicular gene expression in cryptorchid boys at risk of azoospermia. Sex Dev. 2011;5(2):49-59.

19. Kvist K, Thorup J, Byskov AG, Hoyer PE, Mollgard K, Yding Andersen C. Cryopreservation of intact testicular tissue from boys with cryptorchidism. Hum Reprod. 2006;21(2):484-491.

20. Brockbank KG, Song YC, Khirabadi BS, Lightfoot FG, Boggs JM, Taylor MJ. Storage of tissues by vitrification. Transplant Proc. 2000;32(1):3-4.

21. Curaba M, Poels J, van Langendonckt A, Donnez J, Wyns C. Can prepubertal human testicular tissue be cryopreserved by vitrification? Fertil Steril. 2011;95(6):2123.e9-e12. 
22. Wyns C, Curaba M, Martinez-Madrid B, Van Langendonckt A, FrancoisXavier W, Donnez J. Spermatogonial survival after cryopreservation and short-term orthotopic immature human cryptorchid testicular tissue grafting to immunodeficient mice. Hum Reprod. 2007;22(6):1603-1611.

23. Curaba M, Verleysen M, Amorim CA, et al. Cryopreservation of prepubertal mouse testicular tissue by vitrification. Fertil Steril. 2011;95(4):1229-1234.e1.

24. Poels J, Van Langendonckt A, Many MC, Wese FX, Wyns C. Vitrification preserves proliferation capacity in human spermatogonia. Hum Reprod. 2013;28(3):578-589.

25. Baert Y, Van Saen D, Haentjens P, In't Veld P, Tournaye H, Goossens E. What is the best cryopreservation protocol for human testicular tissue banking? Hum Reprod. 2013;28(7):1816-1826.

26. Brook PF, Radford JA, Shalet SM, Joyce AD, Gosden RG. Isolation of germ cells from human testicular tissue for low temperature storage and autotransplantation. Fertil Steril. 2001;75(2):269-274.

27. Pacchiarotti J, Ramos T, Howerton K, et al. Developing a clinical-grade cryopreservation protocol for human testicular tissue and cells. Biomed Res Int. 2013;2013:930962.

28. Wyns C, Van Langendonckt A, Wese FX, Donnez J, Curaba M. Longterm spermatogonial survival in cryopreserved and xenografted immature human testicular tissue. Hum Reprod. 2008;23(11):2402-2414.

29. Van Saen D, Goossens E, Bourgain C, Ferster A, Tournaye H. Meiotic activity in orthotopic xenografts derived from human postpubertal testicular tissue. Hum Reprod. 2011;26(2):282-293.

30. Van Saen D, Goossens E, Haentjens P, Baert Y, Tournaye H. Exogenous administration of recombinant human FSH does not improve germ cell survival in human prepubertal xenografts. Reprod Biomed Online. 2013;26(3):286-298.

31. Sadri-Ardekani H, Mizrak SC, van Daalen SK, et al. Propagation of human spermatogonial stem cells in vitro. JAMA. 2009;302(19):2127-2134.

32. Sadri-Ardekani H, Akhondi MA, van der Veen F, Repping S, van Pelt AM. In vitro propagation of human prepubertal spermatogonial stem cells. JAMA. 2011;305(23):2416-2418.

33. Nickkholgh B, Mizrak SC, Korver CM, et al. Enrichment of spermatogonial stem cells from long-term cultured human testicular cells. Fertil Steril. 2014;102(2):558-565.e5.

34. Nickkholgh B, Mizrak SC, van Daalen SK, et al. Genetic and epigenetic stability of human spermatogonial stem cells during long-term culture. Fertil Steril. 2014;102(6):1700-1707.e1

35. Mirzapour T, Movahedin M, Tengku Ibrahim TA, Haron AW, Nowroozi MR. Evaluation of the effects of cryopreservation on viability, proliferation and colony formation of human spermatogonial stem cells in vitro culture. Andrologia. 2013;45(1):26-34.

36. Izadyar F, Matthijs-Rijsenbilt JJ, den Ouden K, Creemers LB, Woelders H, de Rooij DG. Development of a cryopreservation protocol for type A spermatogonia. J Androl. 2002;23(4):537-545.

37. Zheng Y, Thomas A, Schmidt CM, Dann CT. Quantitative detection of human spermatogonia for optimization of spermatogonial stem cell culture. Hum Reprod. 2014;29(11):2497-2511.

38. Stimpfel M, Skutella T, Kubista M, Malicev E, Conrad S, Virant-Klun I. Potential stemness of frozen-thawed testicular biopsies without sperm in infertile men included into the in vitro fertilization programme. $J$ Biomed Biotechnol. 2012;2012:291038.

39. Kanatsu-Shinohara M, Ogonuki N, Inoue K, et al. Long-term proliferation in culture and germline transmission of mouse male germline stem cells. Biol Reprod. 2003;69(2):612-616.

40. BaertY, Braye A, Struijk RB, van Pelt AM, Goossens E. Cryopreservation of testicular tissue before long-term testicular cell culture does not alter in vitro cell dynamics. Fertil Steril. 2015;104(5):1244-1252.e1-e4.
41. Medrano JV, Rombaut C, Simon C, Pellicer A, Goossens E. Human spermatogonial stem cells display limited proliferation in vitro under mouse spermatogonial stem cell culture conditions. Fertil Steril. 2016;106(6):1539-1549.e8.

42. Gat I, Maghen L, Filice M, et al. Optimal culture conditions are critical for efficient expansion of human testicular somatic and germ cells in vitro. Fertil Steril. 2017;107(3):595-605.7.

43. Ginsberg JP, Carlson CA, Lin K, et al. An experimental protocol for fertility preservation in prepubertal boys recently diagnosed with cancer: a report of acceptability and safety. Hum Reprod. 2010;25(1):37-41.

44. Pietzak EJ 3rd, Tasian GE, Tasian SK, et al. Histology of testicular biopsies obtained for experimental fertility preservation protocol in boys with cancer. J Urol. 2015;194(5):1420-1424.

45. Wyns C, Curaba M, Petit S, et al. Management of fertility preservation in prepubertal patients: 5 years' experience at the Catholic University of Louvain. Hum Reprod. 2011;26(4):737-747.

46. Crabbe E, Verheyen G, Tournaye H, Van Steirteghem A. Freezing of testicular tissue as a minced suspension preserves sperm quality better than whole-biopsy freezing when glycerol is used as cryoprotectant. Int J Androl. 1999;22(1):43-48.

47. Sadri-Ardekani H, McLean TW, Kogan S, et al. Experimental testicular tissue banking to generate spermatogenesis in the future: a multidisciplinary team approach. Methods. 2016;99:120-127.

48. Van Saen D, Gies I, De Schepper J, Tournaye H, Goossens E. Can pubertal boys with Klinefelter syndrome benefit from spermatogonial stem cell banking? Hum Reprod. 2012;27(2):323-330.

49. de Michele F, Poels J, Weerens L, et al. Preserved seminiferous tubule integrity with spermatogonial survival and induction of Sertoli and Leydig cell maturation after long-term organotypic culture of prepubertal human testicular tissue. Hum Reprod. 2017;32(1):32-45.

50. Ahmed EA, Barten-van Rijbroek AD, Kal HB, et al. Proliferative activity in vitro and DNA repair indicate that adult mouse and human Sertoli cells are not terminally differentiated, quiescent cells. Biol Reprod. 2009;80(6):1084-1091.

51. Chui K, Trivedi A, Cheng CY, et al. Characterization and functionality of proliferative human Sertoli cells. Cell Transplant. 2011;20(5):619-635.

52. Sun J, Zhong L, Zhu Y, Liu G. Research on the isolation of mouse Leydig cells using differential digestion with a low concentration of collagenase. J Reprod Dev. 2011;57(3):433-436.

53. Wu X, Goodyear SM, Abramowitz LK, et al. Fertile offspring derived from mouse spermatogonial stem cells cryopreserved for more than 14 years. Hum Reprod. 2012;27(5):1249-1259.

54. Fujita K, Tsujimura A, Miyagawa Y, et al. Isolation of germ cells from leukemia and lymphoma cells in a human in vitro model: potential clinical application for restoring human fertility after anticancer therapy. Cancer Res. 2006;66(23):11166-11171.

55. Geens M, Van de Velde H, De Block G, Goossens E, Van Steirteghem A, Tournaye $\mathrm{H}$. The efficiency of magnetic-activated cell sorting and fluorescence-activated cell sorting in the decontamination of testicular cell suspensions in cancer patients. Hum Reprod. 2007;22(3): 733-742.

56. Geens M, Goossens E, Tournaye H. Cell selection by selective matrix adhesion is not sufficiently efficient for complete malignant cell depletion from contaminated human testicular cell suspensions. Fertil Steril. 2011;95(2):787-791.

57. Hermann BP, Sukhwani M, Salati J, Sheng Y, Chu T, Orwig KE. Separating spermatogonia from cancer cells in contaminated prepubertal primate testis cell suspensions. Hum Reprod. 2011;26(12):3222-3231.

58. Sadri-Ardekani H, Homburg CH, van Capel TM, et al. Eliminating acute lymphoblastic leukemia cells from human testicular cell cultures: a pilot study. Fertil Steril. 2014;101(4):1072-1078.e1. 
Stem Cells and Cloning: Advances and Applications is an international, peer-reviewed, open access journal. Areas of interest in stem cell research include: Embryonic cell stems; Adult stem cells; Blastocysts; Cordblood stem cells; Stem cell transformation and culture; Therapeutic cloning; Umbilical cord blood and bone marrow cells; Laboratory, animal and human therapeutic studies; Philosophical and ethical issues related to stem cell research. This journal is indexed on CAS. The manuscript management system is completely online and includes a quick and fair peer-review system. Visit http://www.dovepress.com/ testimonials.php to read real quotes from published authors..

Submit your manuscript here: https://www.dovepress.com/stem-cells-and-cloning-advances-and-applications-journal 